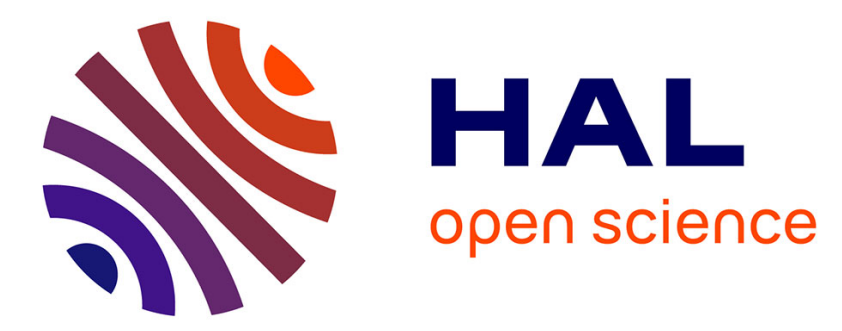

\title{
Deposition of TiO2 thin films by atmospheric plasma post-discharge assisted injection MOCVD
}

Carmen Jiménez, D. de Barros, A. Darraz, Jean Luc Deschanvres, L. Rapenne, Patrick Chaudouët, J.E. Mendez, François Weiss, M. Thomachot, T. Sindzingre, et al.

\section{To cite this version:}

Carmen Jiménez, D. de Barros, A. Darraz, Jean Luc Deschanvres, L. Rapenne, et al.. Deposition of $\mathrm{TiO} 2$ thin films by atmospheric plasma post-discharge assisted injection MOCVD. Surface and Coatings Technology, 2008, 201, pp.8971. 10.1016/j.surfcoat.2007.04.025 . hal-00395626

\section{HAL Id: hal-00395626 https://hal.science/hal-00395626}

Submitted on 16 Jun 2009

HAL is a multi-disciplinary open access archive for the deposit and dissemination of scientific research documents, whether they are published or not. The documents may come from teaching and research institutions in France or abroad, or from public or private research centers.
L'archive ouverte pluridisciplinaire HAL, est destinée au dépôt et à la diffusion de documents scientifiques de niveau recherche, publiés ou non, émanant des établissements d'enseignement et de recherche français ou étrangers, des laboratoires publics ou privés. 


\title{
Deposition of $\mathrm{TiO}_{2}$ thin films by atmospheric plasma post-discharge assisted injection MOCVD
}

\author{
C. Jiménez ${ }^{1 *}$, D. De Barros ${ }^{1,2}$, A.Darraz, J-L. Deschanvres ${ }^{1}$, L. Rapenne ${ }^{1}$, P. Chaudouët ${ }^{1}$, \\ J.E. Méndez ${ }^{1}$, F. Weiss ${ }^{1}$, M. Thomachot ${ }^{2}$, T. Sindzingre $^{2}$, G. Berthomé ${ }^{3}$, F.J. Ferrer ${ }^{4}$ \\ 1 LMGP - UMR 5628- INPGrenoble - Minatec 3, parvis Louis Néel, BP 257, 38016 \\ Grenoble Cedex 1, France. Phone 334565293 34, Fax 33456529301. \\ Carmen.jimenez@inpg.fr \\ 2 AcXys Technologies, 148 rue des Vingt Toises, 38950 Saint Martin le Vinoux, France \\ 3 SIMAP, INPGrenoble-CNRS-UJF, BP 75, 38402 Saint Martin D'Hères \\ 4 Centro Nacional de Aceleradores, Parque Tecnológico Cartuja 93, Av. Thomas A. Edison \\ $s / n .41092$ Sevilla, Spain
}

Keywords : Injection MOCVD, Atmospheric Plasma, titanium oxide, anatase, PECVD

\begin{abstract}
$\mathrm{TiO}_{2}$ thin films have been deposited at low temperature using a new atmospheric pressure deposition process, which combines remote Atmospheric Pressure (AP) Plasma with Pulsed Injection Metallorganic Chemical Vapour Deposition (PIMOCVD). The effects of postdischarge plasma and deposition parameters have been studied with respect to the deposition kinetics, morphology, and microstructure of $\mathrm{TiO}_{2}$ films. It is shown that well-crystallised $\mathrm{TiO}_{2}$ anatase films can be obtained at a temperature of only $275^{\circ} \mathrm{C}$.
\end{abstract}

\section{Introduction}

MOCVD route offers several potential advantages including close control of film stoichiometric, crystallinity and uniformity, versatile control of composition, ability to coat complex shapes and large surfaces. Our laboratory has developed Pulsed Injection MOCVD [1] method, based on a liquid delivery system controlled by a high speed precision micro electro-valve which injects a very small volume of precursors into an evaporator at high temperature $\left(150-300^{\circ} \mathrm{C}\right)$. This method allows to extend the precursor choice to non-volatile compounds [2]. An important feature of PIMOCVD is that the thermal exchange between gas and droplet ensures the total evaporation of precursors even at atmospheric pressure.

Axcys Technologies has commercialized a new dielectric barrier discharge (DBD) plasma system producing low temperature plasma at atmospheric pressure. The post-discharge is sent away from electrodes confinement [3]. In this work, we have combined these two systems working at atmospheric pressure to study the feasibility of low temperature deposition of $\mathrm{TiO}_{2}$ in order to add an alternative and reliable method, PIMOCVD, to the innovative research line AP-PECVD $[4,5]$.

\section{Experimental}

The PIMOCVD experimental set-up has been detailed in previous articles that also report on the deposition of a large variety of precursors [1,2]. Precursors used in this study were $\mathrm{Ti}(\mathrm{OiPr})_{2}(\mathrm{thd})_{2}$, dissolved in octane, and Titanium (IV) oxide acetylacetonate, $\mathrm{TiO}\left[\mathrm{CH}_{3} \mathrm{COCH}=\mathrm{C}(\mathrm{O}-) \mathrm{CH}_{3}\right]_{2}$, dissolved in butanol at concentrations ranging from 0.02 to 0.1 $\mathrm{mol} / \mathrm{l}$. The precursor solution was injected in the evaporator with a frequency of $4 \mathrm{~Hz}$ and 
opening time of $3 \mathrm{~ms}$, yielding droplet sizes of ca. $3 \mu$ l. Evaporation temperature was $280^{\circ} \mathrm{C}$. The precursor vapours were transported by the carrier gas (3.5 to $5 \mathrm{l} / \mathrm{min}$ of $20 \% \mathrm{O}_{2}$ in $\mathrm{N}_{2}$ ) through a heated line to the post discharge zone and mixed with the active species from the plasma. We have used a cylindrical coaxial DBD plasma with an self-regulated frequency of around $100 \mathrm{KHz}$ and electrical power of 600 watt. The internal electrode was $60 \mathrm{~mm}$ in length and $28 \mathrm{~mm}$ in diameter. The gap between electrodes was $1 \mathrm{~mm}$ and the plasma outlet is $2 \mathrm{~mm}$ width [3]. Plasma was created with air reconstituted (20\% of $\mathrm{O}_{2}$ in $\left.\mathrm{N}_{2}\right)$ at total gas flow rates of $15 \mathrm{l} / \mathrm{min}$. Few experiments were also performed with the same flow rate but with lower oxygen concentration in plasma gas to determine the plasma activity. Species activated in the plasma were mixed with the precursors in the post-discharge zone and reached the heated substrate placed at $90 \mathrm{~mm}$ of the plasma outlet, which yield the deposition of a thin solid film. The depositions were performed on 2" silicon substrates heated at temperatures ranging from $200^{\circ} \mathrm{C}$ and $300^{\circ} \mathrm{C}$. The evacuation was ensured by an extracting motor.

The film thickness and refractive index were measured by ellipsometry with at a $632.8 \mathrm{~nm}$ wavelength and $70^{\circ}$ incidence angle. X-ray Photoelectron Spectroscopy (XPS) were performed in a Vacuum Generator using a $\mathrm{Mg}$ line and at two incidence angles $\left(90^{\circ}\right.$ and $\left.30^{\circ}\right)$. Ti 2p, O 1s, C 1s and N 1 peaks were scanned and analysed. Rutherford Backscattering (RBS) and Nuclear Reaction Analysis (NRA) were simultaneously performed on the sample using deuteron particles at $870 \mathrm{keV}$. RBS detection was done at a dispersion angle of $165^{\circ}$ and titanium content was calculated using a bismuth thin film as reference. Oxygen, carbon and nitrogen quantifications were obtained from the reactions ${ }^{12} \mathrm{C}(\mathrm{d}, \mathrm{p}){ }^{13} \mathrm{C}$ and ${ }^{16} \mathrm{O}(\mathrm{d}, \mathrm{p}){ }^{17} \mathrm{O}$ with deuteron particles at $870 \mathrm{keV}$ at and ${ }^{14} \mathrm{~N}(\mathrm{~d}, \alpha){ }^{13} \mathrm{C}$ at $1400 \mathrm{keV}$. In all cases, the detection angle was $150^{\circ}$ and a Mylar filter of $13 \mu \mathrm{m}$ was used.

Fourier Transform Infrared (FTIR) spectra were monitored between 250 and $4000 \mathrm{~cm}^{-1}$ using a Bio-Rad FTS165 spectrometer (200 scans at $20 \mathrm{~Hz}, 4 \mathrm{~cm}^{-1}$ resolution). Raman excitation was performed with a green laser of $514.5 \mathrm{~nm}$ in a LabRam spectrometer (Jobin-Yvon). X-Ray Diffraction (XRD) was preformed at grazing incidence with $\lambda \mathrm{Cu}=1.5406 \AA$. Film crosssections were prepared using a Precision Ion Polishing System (PIPS)-GATAN at low angle $\left(6^{\circ}\right)$ and low voltage $(2.5-3 \mathrm{kV})$ and subsequently studied by Transmission Electron Microscopy (TEM) using a JEOL-2010 instrument with an electron beam energy of 200keV. Surface morphology was analyzed by Scanning Electron Microscopy (SEM) in a SEM-FEG Hitachi 4500 and by Atomic Force Microscopy (AFM) in a Nanoscope II of Digital Instrument in contact mode.

a) General features

\section{Results}

Films deposited from $\mathrm{Ti}(\mathrm{OiPr})_{2}(\text { thd })_{2}$ or from Titanium (IV) oxide acetylacetonate behaved similarly. Films were deposited in remote mode with a plasma outlet-to-substrate distance of $90 \mathrm{~mm}$. With this configuration, the deposition rate is only of $0.4 \mu \mathrm{m} / \mathrm{h}$, and the deposition is isotropic, i.e. vapors reach even the chamber walls. No other publication has shown deposition at so high distance. On the other hand, it means that 3D pieces could be covered under these conditions. Nevertheless, a convergent flow can be created with a nozzle to improve the deposition yield if needed.

Calibration of substrate temperature, using a thermocouple in intimate contact with a silicon substrate, showed that the temperature at the substrate surface was lower (of $40^{\circ} \mathrm{C}$ at $300^{\circ} \mathrm{C}$ and of $25^{\circ} \mathrm{C}$ at $200^{\circ} \mathrm{C}$ ) than inside the substrate holder. It is due to the cooling effect of the high flow rates used for plasma generation, which can not be balanced by the interaction of 
the active particles with the substrate. In next parts of this article, we will specify the temperature measured inside the substrate holder.

Keeping constant air oxygen proportion $(20 \%)$ in the evaporator, oxygen concentration in the plasma discharge varied between 0 and $20 \%$. Firstly, no film could be grown with plasma of pure nitrogen, while a low oxygen proportion (3.3\%) was sufficient to produce $\mathrm{TiO}_{2}$ films. Furthermore, films were grown at temperatures as low as $200^{\circ} \mathrm{C}$. By thermal CVD at the same deposition conditions, depositions starts at $400^{\circ} \mathrm{C}$. It should be mentioned that $200^{\circ} \mathrm{C}$ is lower than the evaporation temperature $\left(280^{\circ} \mathrm{C}\right)$. However, XPS and FTIR measurements showed that the deposited film did not ensue form a precursor condensation. Stability of films was tested by annealing at $500^{\circ} \mathrm{C}$ in air for $1 \mathrm{~h}$. All films stood this treatment, which provokes crystallization in anatase phase and a film thickness shrinking evidenced by a colour change, mainly for the lowest temperature film, due to densification. A plasma treatment at $300^{\circ} \mathrm{C}$ on films deposited at $200^{\circ} \mathrm{C}$ did not induce any change. It is then inferred that the plasma acts differently when used during deposition or during post-deposition annealing.

\section{a) Effect of deposition temperature}

Samples were grown at $200,225,250,275$ and $300^{\circ} \mathrm{C}$ from $\mathrm{Ti}(\mathrm{OiPr})_{2}(\mathrm{thd})_{2}$. Final thickness was $100 \mathrm{~nm}$ at all temperatures for the same injected volume. The refractive index was 2.4 for deposition at $300^{\circ} \mathrm{C}$ and 2.3 for lower temperatures; to be compared to 2.55 for the bulk $\mathrm{TiO}_{2}$ anatase value. Films are very smooth, with rms roughness values of around $1 \mathrm{~nm}$ and mean grain size of $20 \mathrm{~nm}$ independently of deposition temperature.

For all samples, FTIR spectra show the absorbing bands at $440 \mathrm{~cm}^{-1}$ and $260 \mathrm{~cm}^{-1}$ associated to $\mathrm{TO}$ mode of $\mathrm{TiO}_{2}$ anatase [6] any additional band corresponding to contamination from organics products could not be evidenced. Increasing deposition temperature induces the film crystallization, reflected by a decreasing width of the IR bands. The anatase phase was detected at deposition $275^{\circ} \mathrm{C}$ or higher temperatures by Raman spectroscopy (peaks at 143 and $392 \mathrm{~cm}^{-1}$, Fig. 1 [6]) and grazing XRD (reflections are (101), (103) (004) (112) (200)). Films deposited at lower temperatures were amorphous. In TEM observation, anatase formation was confirmed at $300^{\circ} \mathrm{C}$ by indexing of electron diffraction patterns in Fig 2a by comparison with the simulated diffraction spectrum $\left(\mathrm{TiO}_{2}\right.$ anatase $\mathrm{a}=3.78520 \AA \mathrm{A}, \mathrm{c}=$ $9.51390 \AA$ Á, space group I41/amd). High resolution pictures show small crystals where different lattice planes could be clearly resolved (see (101) plane; $d=0.352 \mathrm{~nm}$ in Fig. $2 b$ )

RBS and NRA studies indicated that the films were mainly contaminated by nitrogen and carbon species, films deposited at $200^{\circ} \mathrm{C}$ showing a higher contamination level: $4.5 \% \mathrm{C}$ and $3.7 \% \mathrm{~N}$ to be compared with $3 \% \mathrm{C}$ and $1 \% \mathrm{~N}$ for films deposited at higher temperatures. The $\mathrm{O} / \mathrm{Ti}$ ratio was slightly higher than 2 without influence of deposition temperature. XPS was performed on the same samples without any surface preparation. De-convolution of the Ti, C and $\mathrm{O}$ peaks was performed considering the components summarized in Table 1 [7]. $\mathrm{O} 1 \mathrm{~s}$ peaks were fitted by a main Ti-O contribution (more than $50 \%$ for all temperatures) followed by a Ti-OH contribution. The effect of deposition temperature is to increase the Ti-O contribution and to decrease the Ti-OH contribution (Fig 3) for the two angles of measurement. Ti 2 p peaks were fitted by only one contribution at $458.5 \mathrm{eV}$ with a FWHM of $1.5 \mathrm{eV}$ which corresponds to $\mathrm{Ti}^{+4}$. $\mathrm{N} 1 \mathrm{~s}$ peak was very small with only one contribution at $399.4 \mathrm{eV}$.

\section{b) Effect of titanium to oxygen (Ti/O) reaction ratio}


The Ti/O reaction ratio was varied by changing $\mathrm{TiO}(\mathrm{acac})_{2}$ concentration in solution and oxygen concentrations in plasma flow at a deposition temperature of $300^{\circ} \mathrm{C}$. Fig 4 shows that the deposition rate increases with increasing the $\mathrm{Ti}$ concentration in the solution. The deposition rate follows a same behaviour with the oxygen content in plasma for all $\mathrm{Ti}$ concentrations. It initially increases with the oxygen concentration in plasma and saturates for values higher than $8 \%$. FTIR spectra of Fig 5 also show that, for film deposited with a same deposition rate, increasing the oxygen content favours an enhancement of the crystallization degree, as depicted by a decrease in width of bands at $440 \mathrm{~cm}^{-1}$ and $260 \mathrm{~cm}^{-1}$. Accordingly, films deposited at $6.66 \%$ and $20 \%$ of oxygen have the same deposition rate, but the decrease of $\mathrm{Ti} / \mathrm{O}$ reaction ratio enhances the anatase formation. Besides, if the oxygen concentration in plasma is kept constant at $13 \%$, anatase is more easily detected as films are deposited with lower precursor concentration in the solution, i.e. at lower $\mathrm{Ti} / \mathrm{O}$ reaction ratio. Similar effect was found in [8] when using a plasma formed by hydrogen in helium.

\section{Discussion}

Results presented in this work established that plasma generated from oxygen-containing atmosphere does assist the deposition and plays a dual role: it enhances titanium oxide formation and decreases the energy needed for crystallisation in anatase phase

On the one hand, plasma assistance on the oxide formation is clearly evidenced by a nondependence in temperature of the deposition rate within the whole investigated thermal range. Moreover, oxygen concentration in plasma discharge seems to be crucial for the deposition process since no deposition could be obtained without oxygen uptake in the plasma. Finally, films grown at low temperature $\left(200^{\circ} \mathrm{C}\right)$ consist of $\mathrm{TiO}_{2}$ with relatively low carbon content $(3 \%)$. This result could not be reproduced by thermal CVD.

On the other hand, two main parameters are involved in anatase formation and enhancement of the crystallization degree, namely the substrate temperature (anatase is detected after deposition at $275^{\circ} \mathrm{C}$ ) and $\mathrm{Ti} / \mathrm{O}$ reaction ratio. Our results show that anatase formation is enhanced by increasing the temperature deposition for a constant $\mathrm{Ti} / \mathrm{O}$ reaction ratio and, for a fixed temperature, by decreasing the $\mathrm{Ti} / \mathrm{O}$ reaction ratio.

Other characteristic aspects of our plasma system can be analyzed as follows. Films were deposited using artificial air for plasma generation, which implies a rather high $\mathrm{O}_{2}$ concentration. Few groups use air as plasma gas [9] and, in plasma generated with oxygen, only very low $\mathrm{O}_{2}$ concentrations are used [10]. Furthermore, we used a plasma outletsubstrate distance greater than any other mentioned in literature. Remote PECVD is strongly dependent on electrode-wafer spacing, which is always kept smaller than $15 \mathrm{~mm}$ [11].

In our conditions, anatase formation started at $\mathrm{T}=275^{\circ} \mathrm{C}$ which was lower than for CVD at atmospheric pressure $\left(\mathrm{T} \geq 400^{\circ} \mathrm{C}\right)$ [12] or AP-PECVD $\left(\mathrm{T}=350^{\circ} \mathrm{C}\right)$ [8]. Only one technique working at low pressure was reported to promote anatase formation at lower temperature $\left(210^{\circ} \mathrm{C}\right)$, which used an excimer lamp to activate the process (Photo CVD) [13].

\section{Conclusions}

We have studied the deposition of $\mathrm{TiO}_{2}$ thin films using a new Injection MOCVD process working at atmospheric pressure and combined with remote Atmospheric Plasma. $\mathrm{TiO}_{2}$ films could be deposited at very low temperature $\left(200^{\circ} \mathrm{C}\right)$, even lower than the evaporation 
temperature. When using oxygen concentration in air (20\%) for the plasma gas flow, $\mathrm{TiO}_{2}$ films crystallized in anatase phase from temperatures as low as $275^{\circ} \mathrm{C}$. Oxygen in plasma has a dual role: it enhances $\mathrm{TiO}_{2}$ deposition rates and it provokes its crystallization. No film was deposited when using oxygen-free plasma.

\section{Acknowledgements}

This work has been financially support by the French project "Diademe", funded by the MINEFI.

\section{References}

[1] J.P.Sénateur, F.Weiss, O.Thomas, R.Madar, A.Abrutis. Patent No FR 2707671 (1993) PCT No FR94/00858 (Europe, U.S.A) (1994), US 5945162, Eu EP 730671

[2] J.P. Sénateur, C. Dubourdieu, F. Weiss, M. Rosina, A. Abrutis. Advanced Materials for Optics and Electronics 10 (20) 155-161

[3] M. Bruno, G. Daniel, L. Christian. Patents : FR2692730, 1993-12-24, EP575262, 18-61993, US5458856 11-6-1993.

[4] Chemical Vapor Deposition, Vol 11 (2005). All the volume.

[5] D.W. Shell, M. Pemble. PCT/EP03/09314, US2006/0141290

[6] G. Busca, G. Ramis, J.M. Gallardo Amores, V. Sanchez Escribano, P. Piaggio. J. Chem. Soc. Faraday. Trans. 199490 (20) 3181-3190

[7] F. Zhang, S. Jin, Y. Mao, Z. Zheng, Y. Chen, X. Liu. Thin Solid Films 310 (1997) 29-33.

[8] H. Ha, B.K. Moon, T. Horiuchi, T. Inushima, H. Ishiwara, H. Koinuma. Mat. Scie. And Engineer. B41 (1996) 143-147.

[9] M.C. Kim, D.K. Song, H.S. Shin, S.-H. Baeg, G.S. Kim, J.-H. Boo, J.G. Han, S.H. Yang

Surface and coatings Tech. 171 (2003) 312-316

[10] M.J. Davis, M. Tsanos, J. Lewis, D.W. Sheel M.E. Pemble. Electrochemical Society Proceedings Vol 2003-08 668-675.

[11] G.R. Nowling, S.E. Babayan, V. Jankovic, R.F. Hicks. Plasma Source Sci. Technol. 11 (2002) 97-103.

[12] J.Y Zhang, Q. Fang, J.X. Wu, C.Y. Wu, B.J. O'Sullivan, P.K. Hurley, T.L. Leedham, M.A. Audier, J.P. Sénateur, I.W. Boyd. J. Phys IV France 11(2001) Pr11-295-299

[13] A. Awaluddin, M.E. Pemble, A.C. Jones, P.A. Williams. J. Phys IV France 11(2001)

Pr11-531-537. 
Table 1. Contributions and energies for the XPS peaks de-convolution.

\begin{tabular}{|c|c|c|c|c|}
\hline Element & Contributions and ener & [7] & & \\
\hline $\mathrm{C} 1 \mathrm{~s}$ & $\mathrm{C}-\mathrm{H} / \mathrm{C}-\mathrm{C}$ at $285 \mathrm{eV}$ & $\mathrm{C}-\mathrm{O}$ at $286.4 \mathrm{eV}$ & $\mathrm{C}=\mathrm{O} / \mathrm{O}-\mathrm{C}-\mathrm{O}$ at $287.9 \mathrm{eV}$ & $\mathrm{O}-\mathrm{C}=\mathrm{O}$ at $289.0 \mathrm{eV}$ \\
\hline O1s & $\mathrm{C}-\mathrm{O}, \mathrm{C}=\mathrm{O}$ at $532.6 \mathrm{eV}$ & $\mathrm{M}-\mathrm{OH}$ at $531.5 \mathrm{eV}$ & $\mathrm{M}-\mathrm{O}$ at $530.1 \mathrm{eV}$ & \\
\hline Ti 2p3/2 & $\mathrm{Ti}-\mathrm{O}$ at $458.5 \mathrm{eV}$ & & & \\
\hline $\mathrm{N} 1 \mathrm{~s}$ & $\mathrm{~N}$ at $399.4 \mathrm{eV}$ & & & \\
\hline
\end{tabular}




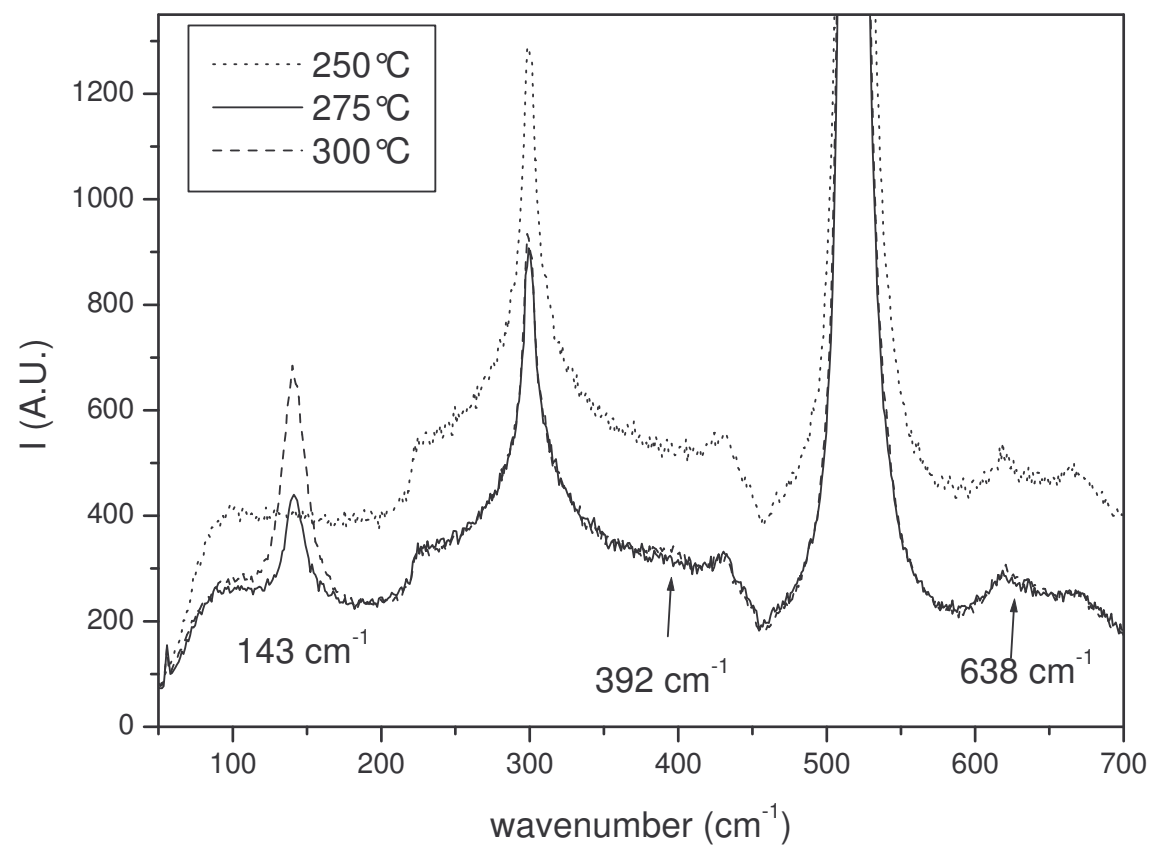

Figure 1 Raman spectra of $\mathrm{TiO}_{2}$ samples deposited from $\mathrm{Ti}(\mathrm{OiPr})_{2}(\text { thd })_{2}$. Peaks associated to anatase are indicated

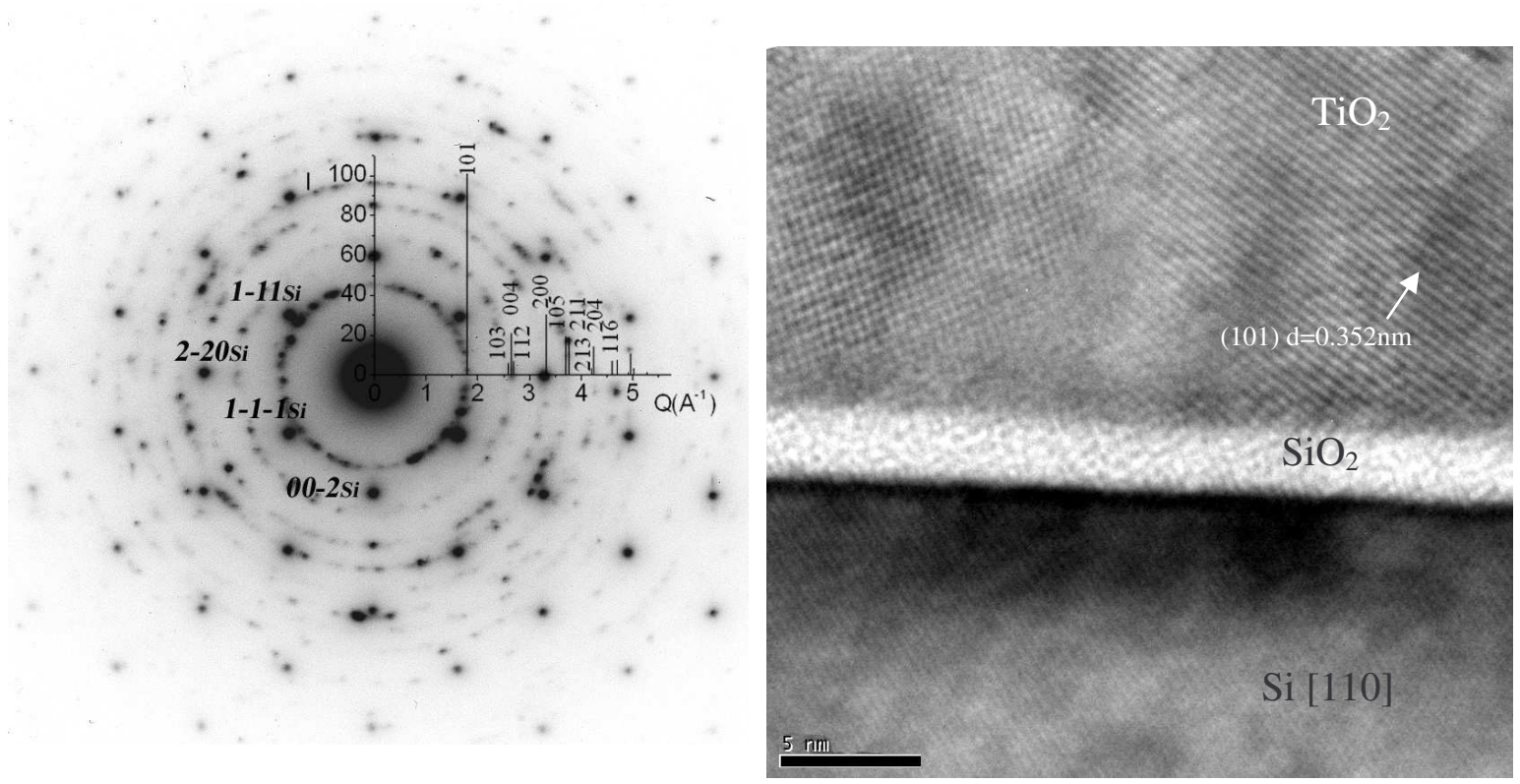

Figure 2 a) Indexation of the electron diffraction pattern of the layer $\mathrm{TiO}_{2}$ interface where the Si substrate is oriented along a [110] zone axis. B) High resolution image of the layer cross 


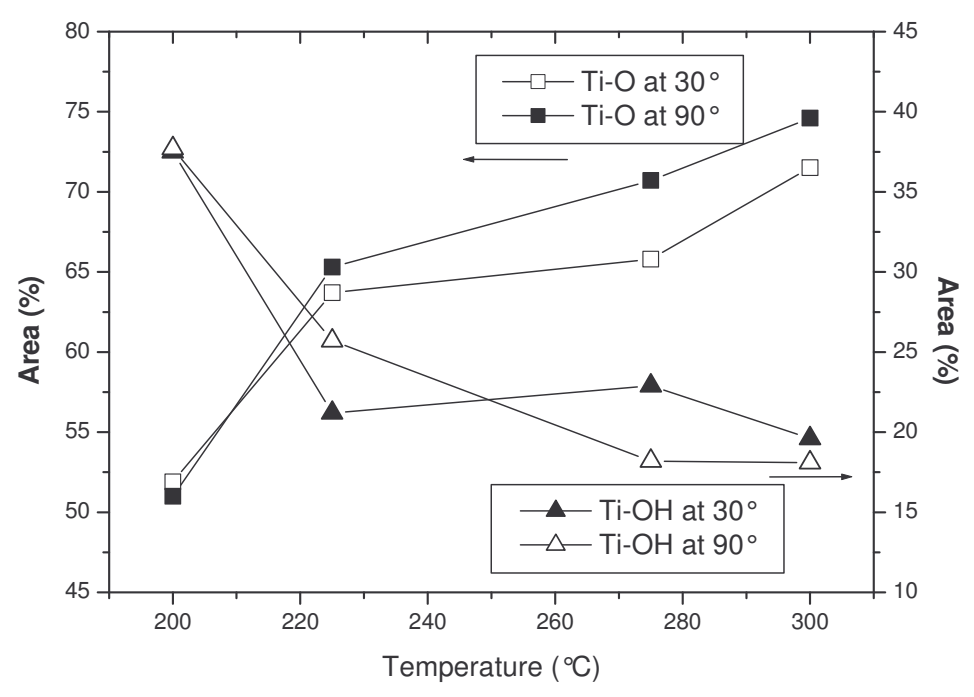

Figure 3 .Temperature dependence of the a) Ti-O and b) Ti-OH contributions from the $\mathrm{O} 1 \mathrm{~s}$ peak de-convolution

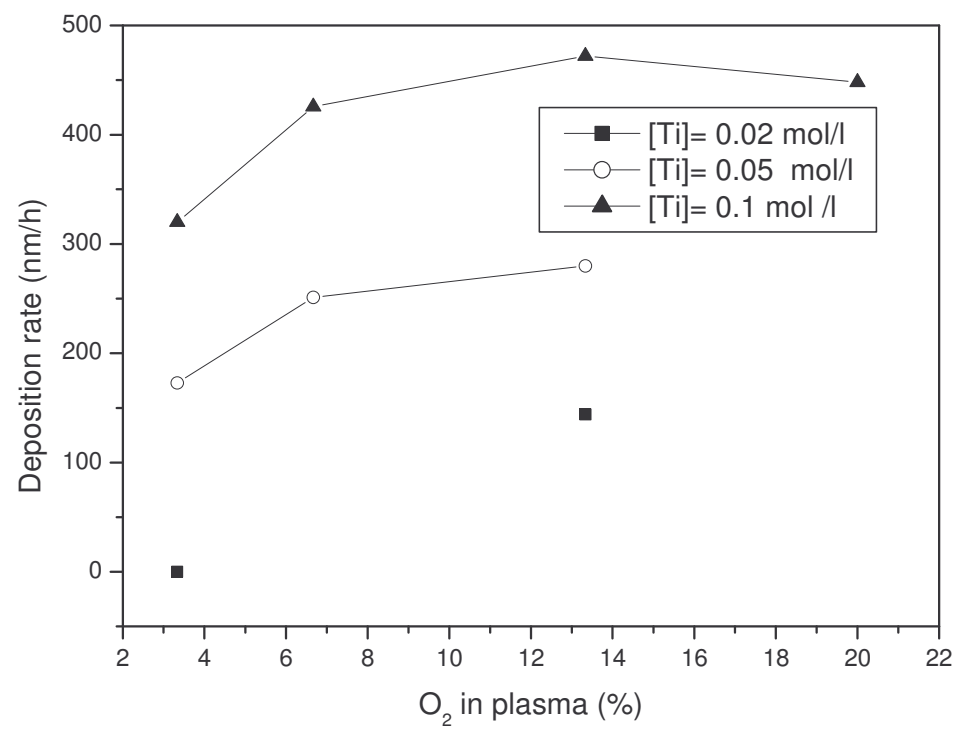

Figure 4. Variation of the deposition rate as a function of oxygen content in plasma for several Ti concentrations of $\mathrm{TiO}(\mathrm{acac})_{2}$ in solution 


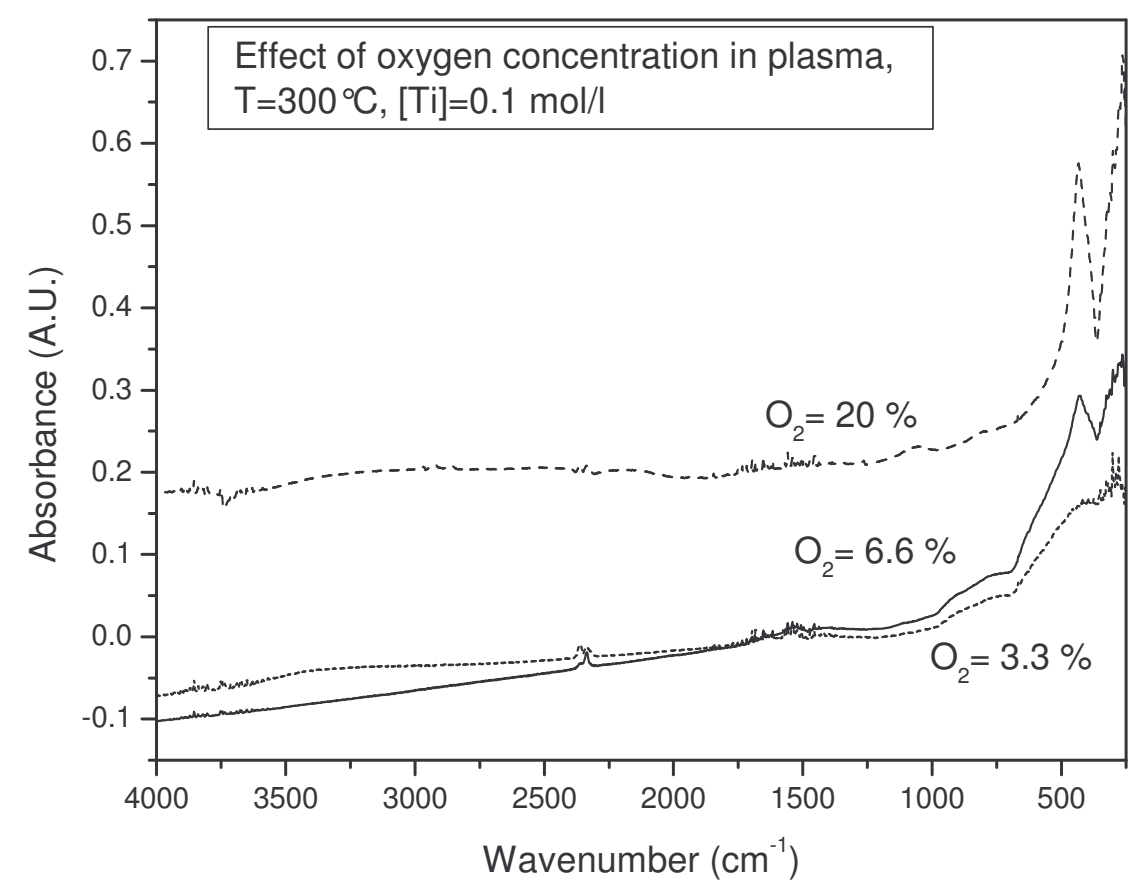

Figure 5 FTIR spectra of samples deposited from $0.1 \mathrm{~mol} / 1 \mathrm{TiO}(\mathrm{acac})_{2}$ solution with different oxygen concentration in plasma 